
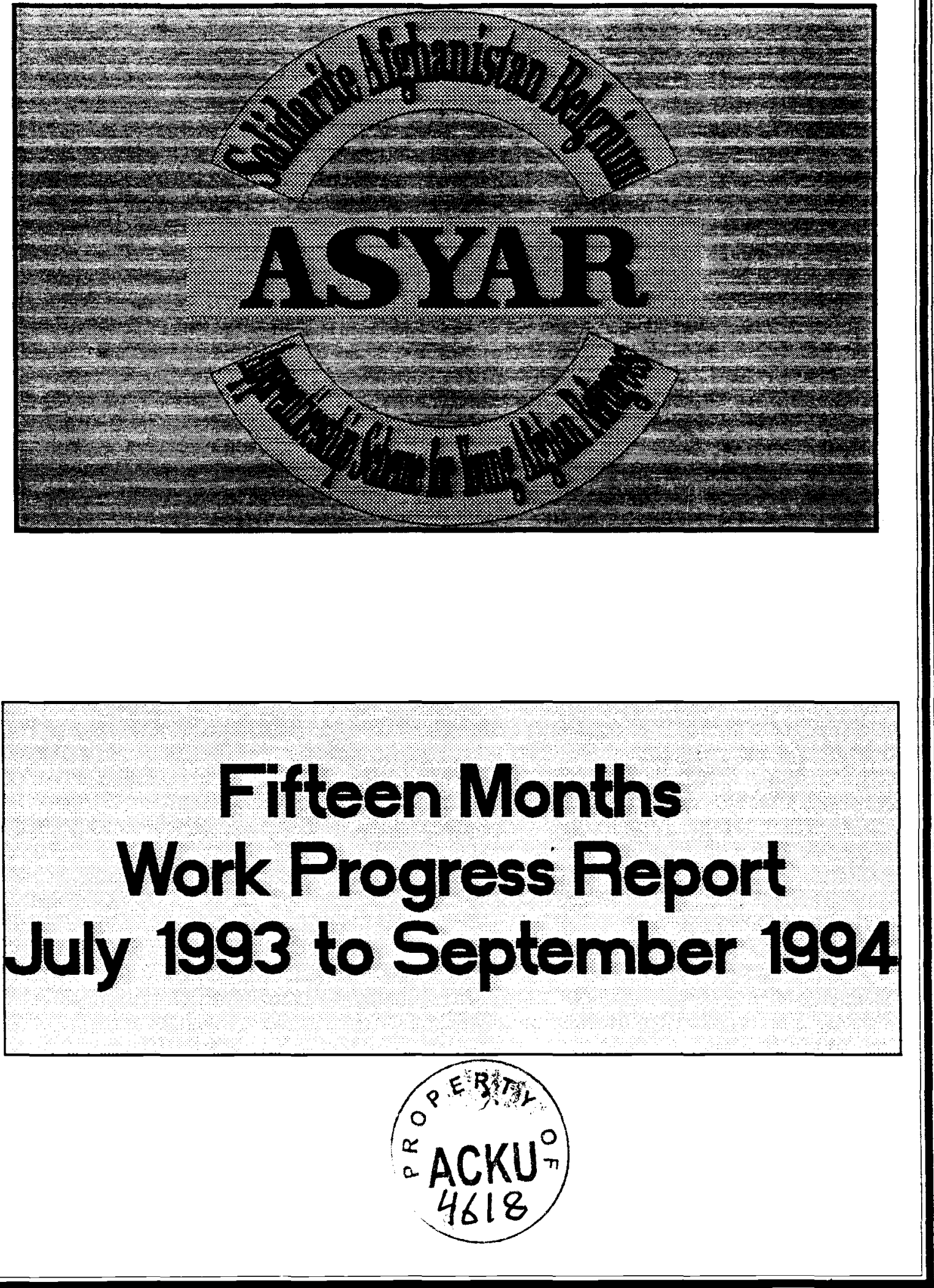
Implementing Agency

Project

Funding Agencies

Contract

Period under review

Location
Solidarite Afghanistan Belgium.

Apprenticeship Scheme for Young Afghan Refugees (ASYAR). European Union (EU) and Belgium government. 660/93/7302/110/696.

July, 1993 to September, 1994.

Integrated Training Center (I.T.C), Peshawar, Islamic Republic of PAKISTAN.

Title

\section{FINAL WORK PROGRESS REPORT.}

\section{A: PROJECT DESCRIPTION:}

Vocational training and income generating department of Solidarite Afghanistan Belgium, Apprenticeship Scheme for Young Afghan Refugees' (ASYAR), since its establishment in 1985 has been training Young Afghans in 27 available trades from refugees camps in Pakistan and Afghans from inside Afghanistan through placement in local workshops.

The development objective of the project is to support the physical and economic recovery of Afghanistan by encouraging development of both the informal education and economic sector.

The immediate objective is to encourage individual self-reliance through skill building and entry to labour market.

\section{The immediate objectives are:}

a) to train young Afghans by apprenticeship scheme,

b) to insert young Afghans trained by ASYAR into income generating activities,

c) to support the level of activities of micro Afghan and Pakistani enterprises in the informal sector in refugees' camps in Pakistan and in Afghanistan.

\section{The beneficiaries are:}

a) young Afghans from refugees' camps in Pakistan and Afghans from inside Afghanistan including $35 \%$ candidates from vulnerable group comprising of widows, orphans and the disabled. Some of the candidates are placed in local workshops and female candidates are trained as group settings (group of 5 trainees) inside the house because of local culture.

b) micro-entrepreneurs : who are provided with a free toolkit costing Rs. 2000/- each against a single placement of apprentice to support their income generating activities. The masters selected in Pakistan are both Pakistani and Afghans. 


\section{OUTPUT ACHIEVED:}

\subsection{Related to immediate objective No. 1:}

Stated: a) 660 under training apprentices per month with masters in local workshops (micro-enterprises).

b) 140 under training apprentices per month with tutors in 28 group settings.

Actual: a) 660 under training apprentices per month with masters in local workshops (micro-enterprises).

b) $\quad 140$ under training apprentices per month with tutors in 28 group settings.

In order to keep the target of 800 under training apprentices per month, each graduated and dropped out apprentice was immediately replaced by a new candidate from waiting lists.

\section{Attainment of obiective No. 1:}

\section{Selection of candidates:}

During the period under review, the field staff of ASYAR have registered 2810 applicants in camps, villages and those who applied to ASYAR offices. Out of this figure, 2148 candidates who could meet the criteria of ASYAR were selected for training through tests and intensive interviews. The age limit is 15 to 20 years while 14 to 45 for the candidates from vulnerable group. Literacy is not required except for the trades of automechanics and radio repairing.

Some candidates were referred to ASYAR by other organizations involved in disabled rehabilitation such as SGAA, ADS, UNHCR, Social Welfare Cell of CAR, Local Shooras and other NGOs for vocational training.

The names of the selected candidates were kept on waiting lists for gradual placement in local workshops and group settings for a certain period of time to learn the trades of their choices. List of trades with duration of training is given in Annex No. 1 (chart).

On the other hand, the field staff of ASYAR have interviewed and selected 654 Pakistani and Afghan workshops' masters and tutors of different trades for training of apprentices. 454 trainer masters have received apprentices for training upto September 30, 1994 while 200 qualified masters are still on waiting lists who will receive apprentices in the next contract period 1994/95.

\section{Placement:}

The target of 800 under training apprentices per month including $35 \%$ candidates from vulnerable group was fully achieved. Out of 2148 selected candidates, 1239 including 256 male disable and 291 female have been placed in local workshops and in group settings of different trades from waiting lists. 909 selected candidates are still on waiting lists (Sep. 30, 1994) who will be placed in the next contract period. 
On account of repatriation of refugees and displaced people to their homeland and some other economical reasons, 262 under training apprentices left training incomplete (dropped out) which shows an average of $2.13 \%$ per month.

The apprentices received Rs. 300/- as monthly stipend to cover their transportation and lunch expenses.

After successful completion of training period, a certificate as well as a standard toolkit costing Rs. 1600/- each were given to the apprentice to start his own business.

Breakdown of under training apprentices per type of beneficiaries is indicated in Annex No. 2 (graph).

In order to increase the activities of ASYAR in Afghanistan, from November 1993 upto July 1994, placement activities were increased in Afghanistan by decreasing the number of apprentices in Pakistan.

Seven sub-offices of ASYAR in Bajaur, Dir, Hangu, Haripur, Mansehra, Mardan and Mian Wali districts of Pakistan were closed and the number of beneficiaries was increased in Ningrahar, Laghman and Kunar sub-offices of Afghanistan On 30, September 1994, 700 under training apprentices per month (88\%) are in Afghanistan and 100 under training apprentices per month (12\%) only candidates from vulnerable group are in district Peshawar of Pakistan.

\section{Follow up:}

From July 1, 1993 to September 30,1994, 13 placement officers of ASYAR have visited each workshop of their related areas twice a week regularly. They kept the attendance record, assessed the relationship between the apprentice and master, progress, quality of training and have encouraged master and apprentice to draw their attention to a successful training.

Once every month an advisor and once every two months a field officer have visited each workshop to check what the placement officer and then advisor have reported. He has also checked the distribution of toolkits to masters and ex-apprentices. The deputy director and field expatriate director have also visited sub-offices and workshops.

Altogether these different levels of checking and reporting were used to assess and reinforce the quality and quantity of training.

\section{Theoretical courses:}

In order to support the practical work of the apprentices and give them opportunity to inquire questions raised during the practical work in workshop, ASYAR provides theoretical courses in the trades of automechanics and radio repairing to its under training apprentices once in each 6 months.

The trainees have the opportunity to attend these courses three times in their training period of 17 months. Teaching books written in Pushto language by the instructors of the programme and related stationery are provided by ASYAR. 
The apprentices in the trade of automechanics receive a two weeks driving training course in the last month of their training period.

Two theoretical courses of automechanics and radio repairing as well as driving training course were based in Mianwali sub-office in Pakistan, where the apprentices in the mentioned trades attended these courses one day per week.

Beside that, automechanics workshop and service station provided free repairing and service to the vehicles of UNHCR, Afghan Commissionerate and NGOs working for Afghan Refugees in the area.

The other two mobile courses of automechanics and radio repairing as well as driving training courses have been functioning in Ningarhar, Kunar and Laghman provinces inside Afghanistan where they taught the apprentices in each sub-office for one month in turns.

As ASYAR decided to close Mianwali sub-office in June 1994, these courses were shifted to Afghanistan as well.

The first group of theoretical courses will continue its functioning to support the under training apprentices of ASYAR in Afghanistan while the second group of courses, now in the stage of preparation, would be well equipped and start its functioning. They will teach microentrepreneurs of automechanics and radio repairing in local bazaars and cities of Ningarhar, Kunar and Laghman provinces in near future, according to the survey's recommendation conducted in February/March 1994 and mentioned in the project document 1994/95 in order to upgrade and reinforce their technical knowledge.

In the period under review, automechanics, radio repairing and driving training courses have functioned in Mianwali, Kunar, Laghman and Ningarhar sub-offices.

A total of 215 apprentices have attended automechanics course, 229 apprentices have attended radio repairing course and 62 apprentices in the trade of automechanics received motor driving training course. 138 text books and related stationery have been distributed to them.

160 vehicles of UNHCR, CAR and NGOs have been repaired and serviced by automechanics workshop and service station of ASYAR Mianwali sub-office.

It should be mentioned that literacy courses for female trainees in 10 group settings in Jalalabad were started on experimental bases which were found successful. Therefore, this activity was extended to all group settings of ASYAR.

\subsection{Related to immediate objective No. 2:}

Stated: $\quad$ From July 1, 1993 to September 30, 1994, 980 graduated apprentices benefited with standard toolkits related to trades they learnt.

Actual: a: $\quad 827$ apprentices have completed their training period successfully in local workshops and received standard toolkits costing Rs. $1600 /=$ each after graduation. 
b: $\quad 150$ standard toolkits have been distributed to female trainees in group settings in advance.

\section{Attainment of objective No. 2:}

\section{Toolkits distribution to ex-trainees:}

In the period under review, 977 standard toolkits have been distributed to the graduated apprentices in order to insert them in labour market.

It should be elaborated that the above mentioned toolkits in section (a) have been received by extrainees after graduation who completed their training period in local workshops.

The toolkits mentioned in section (b) have been received by the female apprentices in group settings in the beginning of training. Because they use these kits as training materials during the training and own them after graduation as standard toolkits. They are not supposed to receive another standard toolkit after graduation.

\section{2: Monitoring of ex-apprentices:}

After the completion of training, the graduated apprentices are given a 3 months length to find job for themselves.

The monitoring staff of ASYAR trace them with the help of placement officers to collect detailed information about their employment status. After every six months, the employment rate is calculated.

The monitoring staff have interviewed 181 ex-apprentices of the last contract who had graduated before July 1993 and 724 apprentices of the present contract 1993/94.

Those ex-trainees who graduated in the last three months of the present contract (July, August, September 94), will be monitored in the next contract period according to monitoring procedure.

Out of the total figure of 905 monitored ex-apprentices 64, ex-trainees have opened their own workshops, 555 have been employed by others, 201 ex-trainees are still unemployed, searching for work and 85 ex-trainees (refugees / displaced) who have repatriated to their home districts could not be traced (out of district).

The employment rate is $75.49 \%$ by 30 , September 1994 . List of monitored ex-apprentices per employment status is indicated in Annex No. 3 (graph).

Graduation ceremonies were celebrated in Hangu, Mansehra, Haripur, Bajaur, Dir, Mardan, Peshawar, Mianwali and Ningarhar sub-offices.

The number of graduated apprentices since the start of apprenticeship programme in 1985 upto the end of 1994, is shown with the help of a graph in Annex No. 4. 


\subsection{Related to immediate objective No. 3 :}

Stated: a: $\quad$ From July 1, 1993 to September 30, 1994, 1026 micro-entrepreneurs benefited with toolkits of their choices costing Rs.2000/= each, against each placement of apprentice.

b: To study the feasibility of a credit programme to settle up a small scale experimental credit programme.

Actual: a: $\quad 929$ toolkits have been distributed to micro-entrepreneurs against placement of apprentices in their workshops.

It is mentionable that 140 female candidates were placed in group settings with tutors. The tutors are not supposed to get toolkits, because they are giving training in the house and get monthly salary.

b: According to the consultancy and recommendations of surveyor (Mrs. Jane Thomas) selected by European Union Peshawar, the credit programme was postponed to the next contract period 1994/95. The survey was conducted in February/March 1994.

\section{B. MPLEMENTING STRATEGY, PROBLEMS AND CONSTRAINS:}

\section{Implementation process:}

The activities of ASYAR were implemented through main office in Hayat Abad. Peshawar, 7 sub-offices in Bajaur, Dir, Mardan, Haripur, Mansehra, Hangu, Mianwali in Pakistan and 3 suboffices of Ningarhar, Kunar and Laghman in Afghanistan.

In order to increase the number of beneficiaries in Afghanistan and decrease in Pakistan, as mentioned in the project document, since September 1993 the placement activities were increased in the 3 sub-offices of Afghanistan and upto June 31st 94, 7 sub-offices in Pakistan were closed.

The situation on 30 September 1994 is, 700 under training apprentices per month in the 3 suboffices in Afghanistan and 100 under training apprentices (candidates from vulnerable group only) are in district Peshawar of Pakistan.

If the security conditions allow us, new sub-offices will be opened in Kabul, Logar and Wardak provinces of Afghanistan in coordination with other E.U. financed NGOs.

\section{Objectives and outputs:}

Please see above actual (b). 


\section{Inputs (Financial and stafn:}

The local staff of ASYAR was 46 Afghan employees. There were one expatriate field director and one expatriate finance/administrative manager. The expatriates shared their services between ASYAR and TTC/PMT projects.

Financial report is presented separately.

In June 1994, Solidarity Afghanistan Belgium did not renew the service contract of expatriate field director and instead an Afghan was appointed as field director on 1st August 1994.

\section{INFORMATION SOURCE AND METHODOLOGY:}

Heavy monitoring procedure of ASYAR programme such as visit of each workshop and group setting 2-3 times a week by placement officer, once a month by an advisor, once every two months by a field officer and visits of sub-offices and workshops by deputy director and field expatriate director took place on regular basis, and each situation was reported to administration.

\section{INDICATORS:}

The number of candidates on waiting lists shows the demand for ASYAR programme, as we had 639 able, 126 disabled and 144 female candidates on waiting lists on 30 September 1994.

On the other hand, 200 qualified micro-entrepreneurs and female tutors are on waiting list for masters. In addition, other NGOs involved in disability field introduce disabled to ASYAR on regular basis.

\section{Project impact, overall assessment and recommendations:}

\section{Beneficiaries:}

a. Young Afghan refugees from refugees' camps in Pakistan and Afghans from inside Afghanistan who were placed as apprentices in local workshops and group settings including $35 \%$ candidates from vulnerable group such as widows, orphans and the disabled.

b. Micro-entrepreneurs who were provided with a free toolkit against a single placement of apprentice to support their income generating activities. 
The direct beneficiaries of the project were as under:

a) Partially completing program (dropped). 262

b) Graduated apprentices 977

c) New placed to replace graduates and dropped out 1239

d) Trainer masters and tutors 454

Total: $=2932$

The indirect beneficiaries are:

-Family members of masters $(454 \times 7)=$

ASYAR does not count the family members of dropped out or new placements as beneficiaries because they are not yet able to support their families.

\section{Development goals:}

- In the period under review, out of 905 monitored ex-apprentices, 619 ex-trainees have found jobs according to the report of monitoring staff. They are self-sufficient and can support their families.

- Soap making trade was included in the programme in December 1992. 15 widows have been trained so far. The ex-trainees have started production of soap inside their houses on a small scale. Each of them can produce $40-100 \mathrm{Kg}$ soap per day and have sufficient income. They are using mostly local raw materials.

Consulting ASYAR's office in Jalal Abad, two persons from the city made small soap making factories such as Ningarhar Soap and Wahdat Soap who hired ASYAR's extrainees for soap production.

- Literacy courses were introduced in 10 group settings of female trainees during the contract period on experimental bases. It was found successful, therefore it was gradually extended to all group settings during the year. In result, literacy courses for female trainees besides skill training was included in the proposal for 1994/95 contract as part of ASYAR activities.

- 16 ex-trainees of ASYAR have been hired by other organizations such as 2 tractor mechanics and welder by MADERA's tractor repairing workshop in Kunar, 4 disabled by ISRA technical training center in Jalalabad as instructors, 6 automechanics by ACLU as mechanics, 2 by Arab organization as electronics instructors and 2 by Save the Children as mechanics in Peshawar. 


\section{Problems faced:}

In November 1993, the borders between Pakistan and Afghanistan were closed by Pakistani authorities. It was very difficult for ASYAR to purchase toolkits and other training materials in Peshawar and transport them to Afghanistan. However, by encouraging Afghan traders to supply hardware and machinery to us in Jalal Abad, we succeeded to solve the problem and deliver toolkits to masters and ex-trainees on time in Afghanistan.

The same problem was faced by staff members working in Afghanistan and project vehicles to ply between Afghanistan and Pakistan as S.A.B. was not registered as NGO with the central government of Pakistan. This problem was also solved in September 1994.

A toyota pick up was stolen on Jamrud Road near Hayatabad in August 94. The pick up was comprehensively insured with Adamjee Insurance Company who will refund ASYAR in November 1994. A second hand toyota pick up would be purchased with pre-approval of European Union Office in Peshawar.

\section{Lessons Learnt:}

A. During the period under review the programme was implemented in Pakistan and in Afghanistan. The experience gotten indicates that vocational training programme is more effective inside Afghanistan than in Pakistan. Because it helps peace and resettlement of displaced / refugees.

B. It was learnt that in vocational training and income generating programme's productive trades are more effective because the trainees after graduation do not depend on employment and become self employees. They take part in production required by the community such as carpet making, carpentry, black smith, mat making, shoe making, tinsmith, bakery, soap making and candle making. Most of the raw materials of the mentioned productions are locally available.

C. Close relation with local authorities and on time reporting help smooth running of the activities and support of local governments.

\section{Recommendations:}

A. Vocational training and income generating activities should be extended to rural areas in order to help in the resettlement of refugees and displaced people inside Afghanistan.

B. The number of trades especially productive ones should be increased and local traditional small industries should be included in the programme.

C. Number of female trainees should be increased within the target or by increasing the target.

Ghulam Gul

Programme Director

Peshawar, November 20, 1994 
Implementing Agency :

Project

Funding Agencies :

Contract :

Period under review :

Location
Solidarite Afghanistan Belgium.

Annex \# 1.

Title : List of categorical trades and tradewise training period.

\begin{tabular}{|c|c|c|}
\hline $\begin{array}{l}\text { CATECORIES } \\
\text { OFTRADES }\end{array}$ & W. & $\begin{array}{l}\text { TRA INING PORIODS } \\
\text { (LN MONTHS) }\end{array}$ \\
\hline \multirow[t]{4}{*}{ AUHOMECHAMTCS } & ENGINE & 17 \\
\hline & RICKSHAW & 17 \\
\hline & TRACTOR & 17 \\
\hline & MOTOR CYCLE & 13 \\
\hline \multirow[t]{2}{*}{ COAHIES } & TALORING & 10 \\
\hline & EMBRODERY & 7 \\
\hline \multirow[t]{3}{*}{ BrReHRYY } & RADIO REPAIR & 17 \\
\hline & ENGINEERING WORKS & 14 \\
\hline & WIRING & 13 \\
\hline \multirow{2}{*}{ GAMDIGRIFI? } & EANDICRAFT & 7 \\
\hline & CARPET WEAVING & 12 \\
\hline WEAHHAR TORES & SHOE MAKING & 12 \\
\hline \multirow[t]{6}{*}{ FiFYA, NORRS } & PANEL BEATING & 14 \\
\hline & WELDING & 12 \\
\hline & BLACKSMITH & 12 \\
\hline & IINSMITH & 12 \\
\hline & THRESHER MAKING & 12 \\
\hline & LATHING & 14 \\
\hline PAINITYG & PAINTING & 11 \\
\hline \multirow[t]{7}{*}{ OTHFRS } & MEMORIZING HOLY QURAN & 17 \\
\hline & WATCH REPAIR & 12 \\
\hline & PHOTOGRAPHY & 10 \\
\hline & BAKERY & 10 \\
\hline & BICYCLE & 10 \\
\hline & VOLCANIZING & 6 \\
\hline & SOAP MAKING & 7 \\
\hline TOOD WORK & CARPENTRY & 14 \\
\hline
\end{tabular}




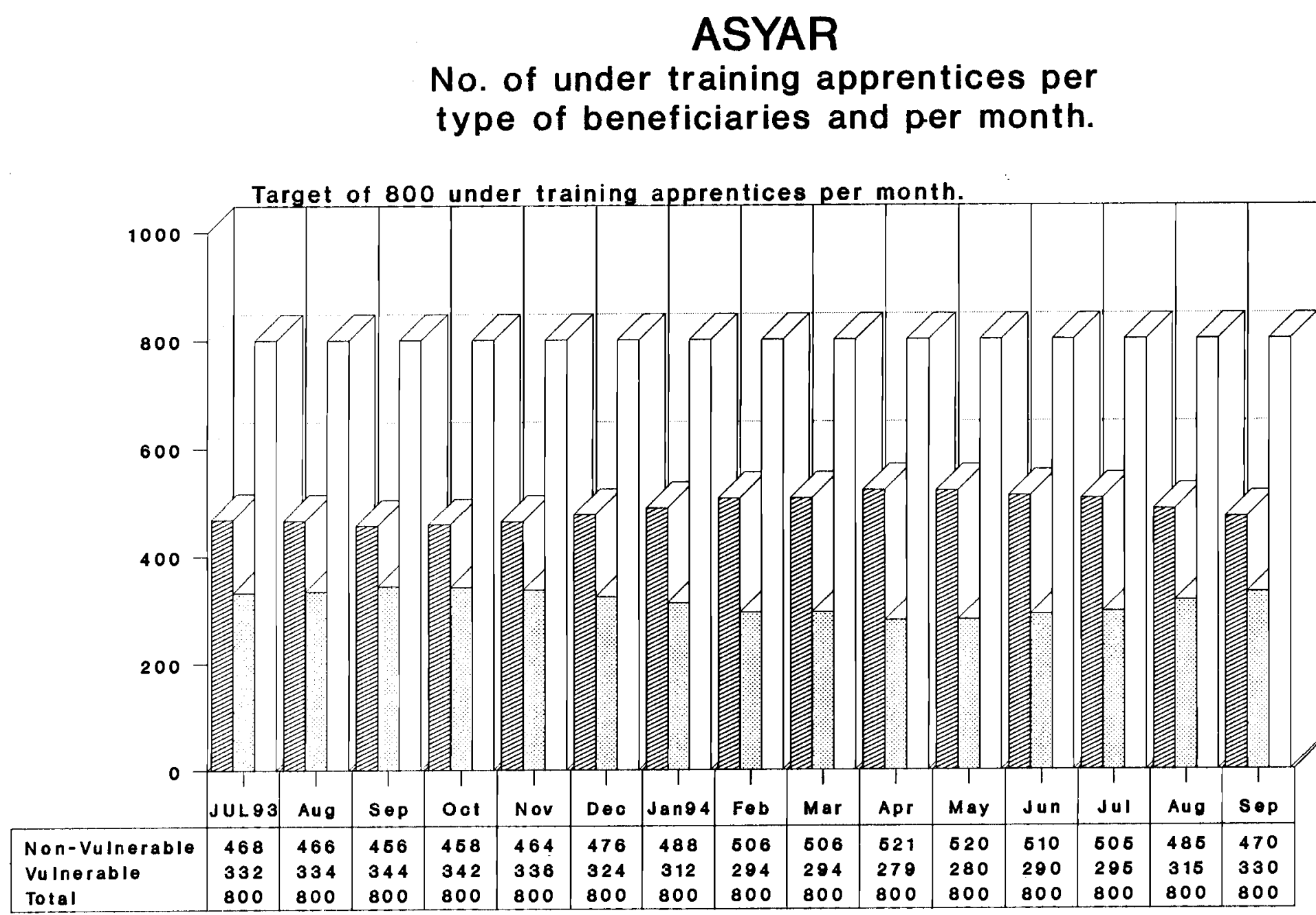

(From July 1993 to September 1994)

WNon-Vulnerable Vulnerable $\square$ Total

Annex \# 2. 


\section{ASYAR.}

Monitored ex-apprentices per

employment status (in \%).

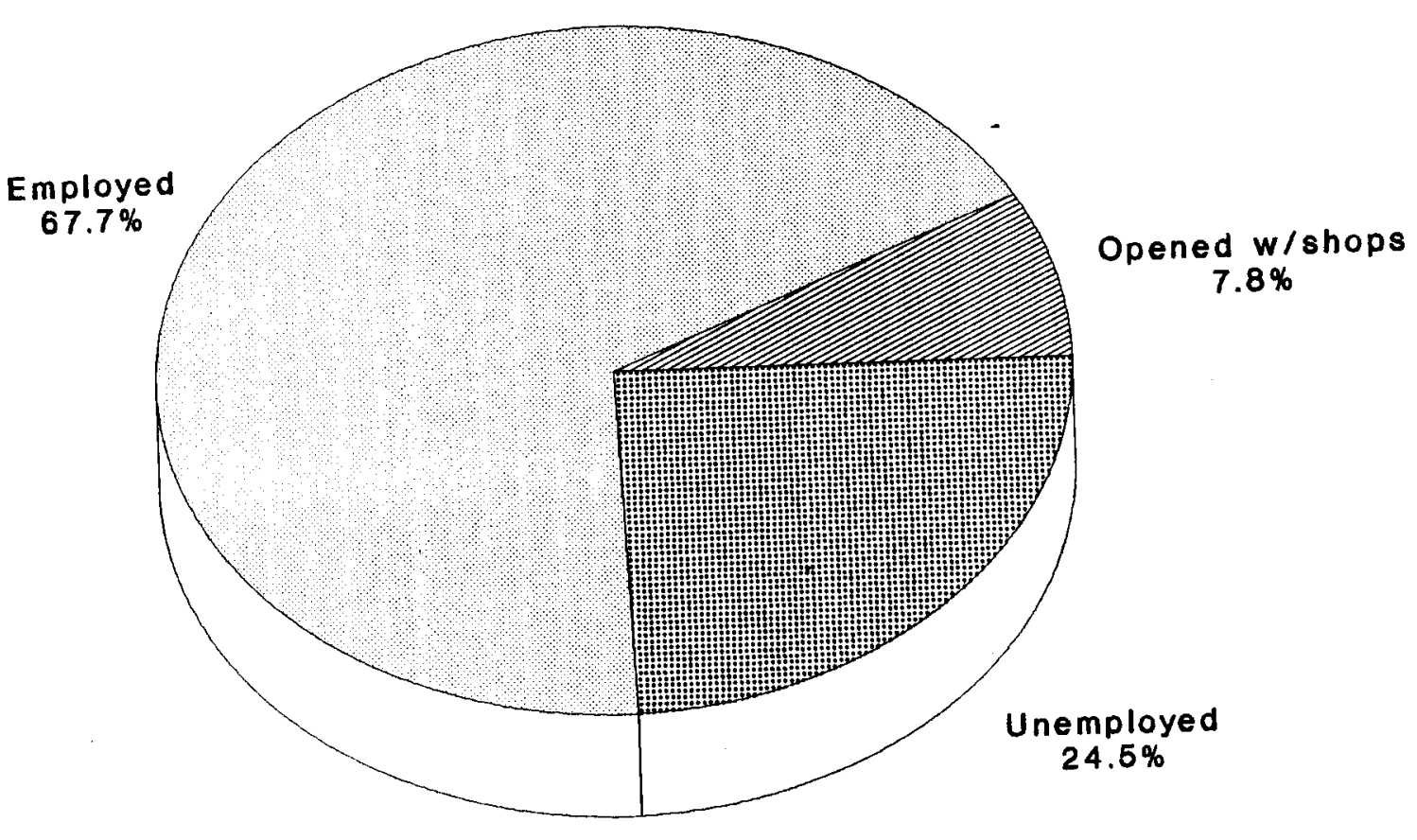

(From July 1993 to September 1994).

Annex \# 3. 
ASYAR

No. of grauated apprentices per year and country.

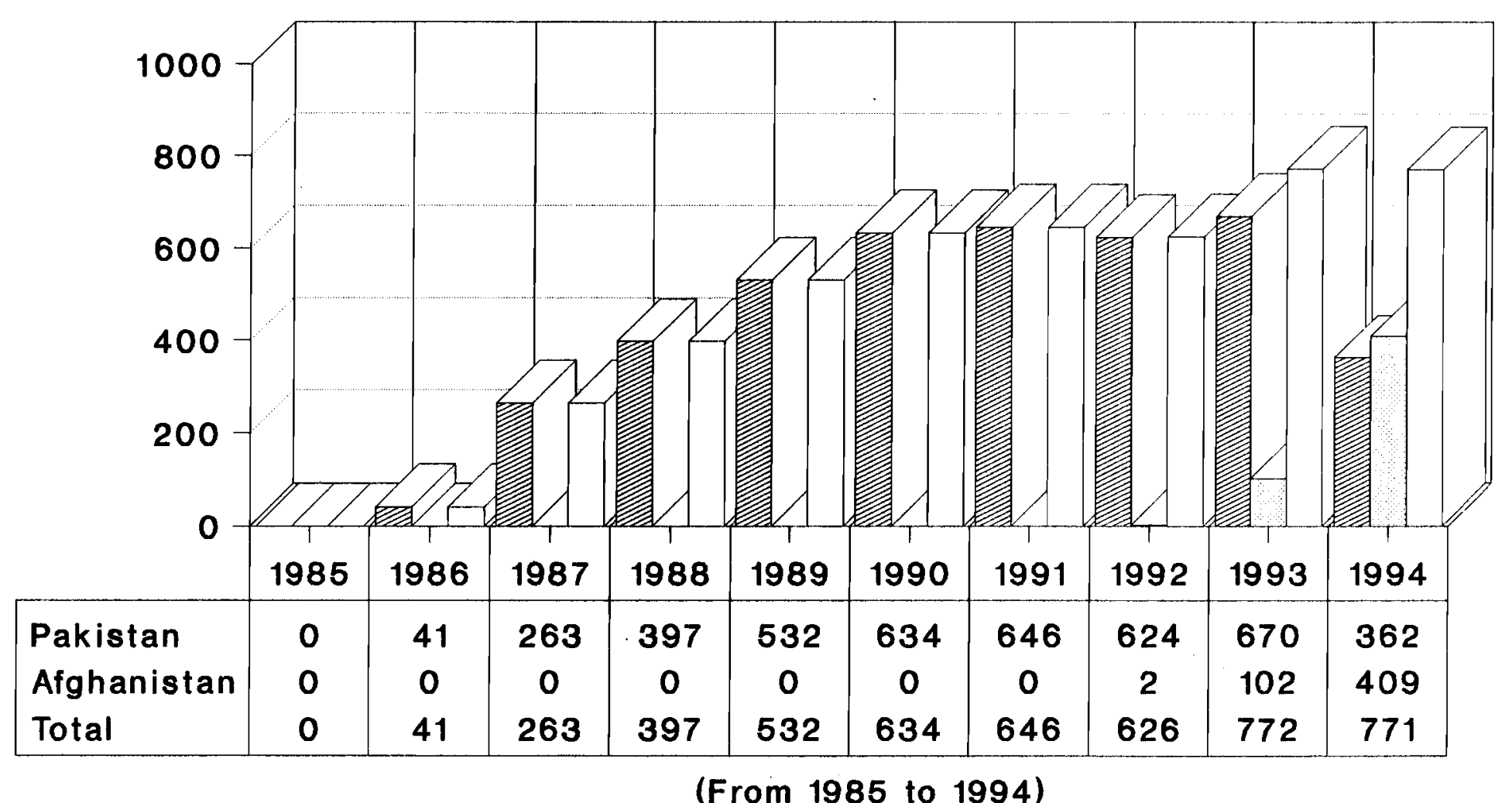

(From 1985 to 1994)

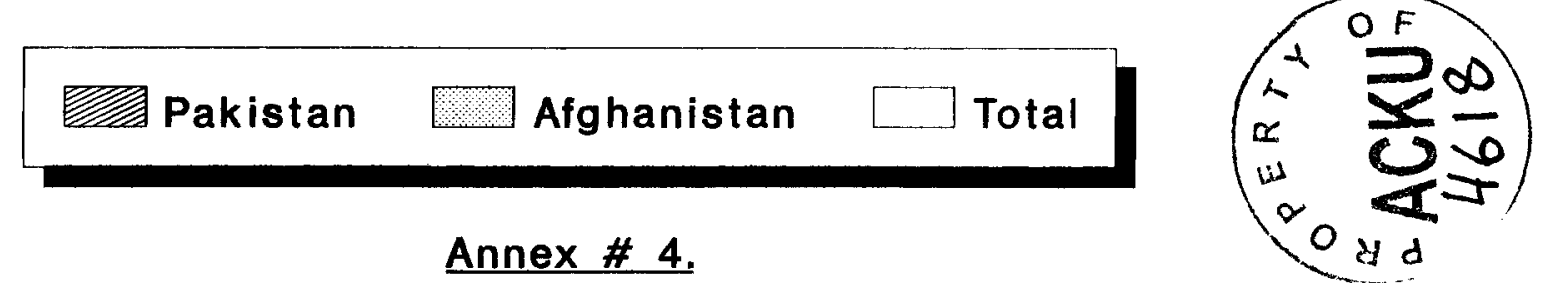

